\title{
STUDY KINETIKA REAKSI : EKSTRAK KUNYIT KUNING DALAM PENYEMBUHAN PENYAKIT MAAG
}

\author{
Chofizah Nurul Hikmah*1 \\ ${ }^{1}$ Pendidikan Kimia, FMIPA, Universitas Negeri Padang, Indonesia \\ *E-mail : chofizahnuru1253@gmail.com
}

\begin{abstract}
Abstrak : Study ini bertujuan untuk membuat ekstrak kunyit untuk penyembuhan penyakit maag. Metode yang dilakukan adalah eksperimen dan uji aktivitas katalitik secara langsung terhadap tanaman kunyit .Tahapan pertama dilakukan dengan pembuatan ekstrak dari tanaman kunyit. Uji aktivitas langsung dilakukan dengan variasi yang sama selama jangka waktu yang lama ( 1 bulan ). Hasil eksperimen membuktikan bahwa ekstrak tanaman kunyit dapat menyembuhkan penyakit maag. Keadaan optimum ekstrak tanaman kunyit tercapai dalam kurun waktu 1 bulan. Penyembuhan ini diduga karena aktivitas katalitik ekstrak tanaman kunyit terhadap penyakit maag. kunyit mengandung senyawa yang berguna sebagai obat yang disebut kurkuminoid .
\end{abstract}

Kata kunci : katalitik, ekstrak kunyit,maag, obat dan kurkuminoid

\section{PENDAHULUAN}

Katalitik $^{(1-25)}$ merupakan suatu proses dalam mempercepat proses reaksi kimia. Reaksi kimia ${ }^{(26-35)}$ yang akan diamati adalah suatu proses reaksi secara langsung dalam tubuh manusia. Reaksi kimia sangat penting bagi kehidupan, di mana suatu kehidupan tidak akan berjalan tanpa adanya proses reaksi ${ }^{(41-48)}$. reaksi kimia berlangsung dengan adanya bantuan dari katalis. Katalis ${ }^{(49-55)}$ terbagi atas dua yakni katalis alami ${ }^{(56-60)}$ dan katalis buatan ${ }^{(61-65)}$. Di mana katalis alami yang akan diamati atau diuji adalah ekstrak ${ }^{(66-67)}$ tanaman kunyit.

Kunyit $^{(8)}$ digunakan sebagai obat herbal ${ }^{(68)}$ atau tradisional sudah sejak dahulu. Kunyit sangat berpengaruh dalam proses penyembuhan penyakit ${ }^{(69-70)}$ terutama penyakit maag ${ }^{(10)}$. kunyit sangat mudah ditemukan dalam kehidupan sehari-hari Kunyit memiliki ciri berwarna kuning ${ }^{(71)}$ dengan tekstur yang lembut sehingga sangat mudah untuk diiris. Selain untuk menyembuhkan penyakit maag 
kunyit juga bisa diaplikasikan untuk perawatan wajah $^{(72)}$ dalam menyembuhkan jerawat. Untuk perawatan wajah biasanya kunyit dijadikan masker wajah ${ }^{(73)}$.

Proses pada penyembuhan penyakit maag dengan menggunakan ekstrak kunyit ${ }^{(744)}$ berlangsung selama jangka waktu 1 bulan. Di mana dalam jangka waktu sebulan seseorang diharuskan meminum ekstrak ${ }^{(75-85)}$ dari tanaman kunyit sebanyak 2 kali sehari pagi dan malam setelah makan. Selama proses penyembuhan berlangsung telah nampak perubahan yang signifikan pada tubuh orang tersebut. Hal ini dibuktikan dengan dalam jangka waktu 1 Minggu. penggunaan ekstrak tanaman kunyit ini maag yang awalnya sangat akut sekarang sudah berangsur-angsur sehat tetapi tidak terlalu nampak atau signifikan perubahan dari penderita maag. Pada Minggu - minggu berikutnya sudah terlihat perubahan yakni dari yang awalnya tidak suka makan dalam artian susah untuk makan menjadi lebih lahap ketika makan serta pada Minggu keempat (terakhir) badan si penderita maag tersebut sudah sangat sehat nafsu makannya semakin bertambah, tidak pernah terasa lagi nyeri ${ }^{(86)}$ di bagian perut ${ }^{(87)}$ (lambung) ${ }^{(88)}$ serta dia sudah bisa kembali beraktivitas seperti semula.

Maag $^{(89-90)}$ merupakan suatu penyakit ${ }^{(91-100)}$ yang sering dijumpai pada masyarakat baik itu di Indonesia maupun di negara lainnya . maag adalah penyakit yang terdapat pada perut di bagian lambung manusia. Maag terdiri atas maag akut $^{(101)}$ dan maag sedang(ringan) ${ }^{(102)}$ serta ada juga gejala-gejala maag. Maag akut adalah level tertinggi dari penyakit maag itu sendiri biasanya maag akut disebabkan oleh adanya infeksi ${ }^{(103)}$ dari bakteri ${ }^{(104)}$ serta maag biasanya karena luka ${ }^{(105)}$ yang ada di bagian dalam lambung.

Obat $^{(106)}$ adalah zat yang sering digunakan untuk menghilangkan ${ }^{(107)}$ dan meredakan $^{(108)}$ berbagai macam gejala penyakit. Obat tidak hanya dapat menyembuhkan penyakit pada fisik ${ }^{(109)}$ tetapi juga dapat menghilangkan kelainan psikis $^{(110)}$ pada manusia. Obat tebagi atas 2 yakni obat herbal dan obat kimia(buatan).

Proses ini dilakukan untuk mengetahui apakah ekstrak tanaman kunyit dapat menyembuhkan penyakit maag. Tujuan dari penelitian ini adalah untuk 
membuktikan pengaruh $^{(111-120)}$ ekstrak tanaman kunyit dalam proses penyembuhan penyakit maag.

\section{METODE}

\section{Alat Dan Bahan}

Peralatan yang digunakan adalah Parutan( Fackelmann Double Grater Productnation),Pisau(Ideal), Saringan (Stainless Stell), Gelas Keramik, Mangkok Keramik dan Kamera (Xiaomi Redmi Note 5A)

Bahan yang digunakan adalah kunyit dari Daerah Dusun Bangko, Bangko Kabupaten Merangin Kota Jambi, Air( Leminerale )

\section{Prosedur Kerja}

\section{a. Persiapan Sampel}

Sampel diambil dari lokasi terdekat dari rumah (yaitu di daerah Dusun Bangko, Bangko Kabupaten Bangko Kota Jambi).

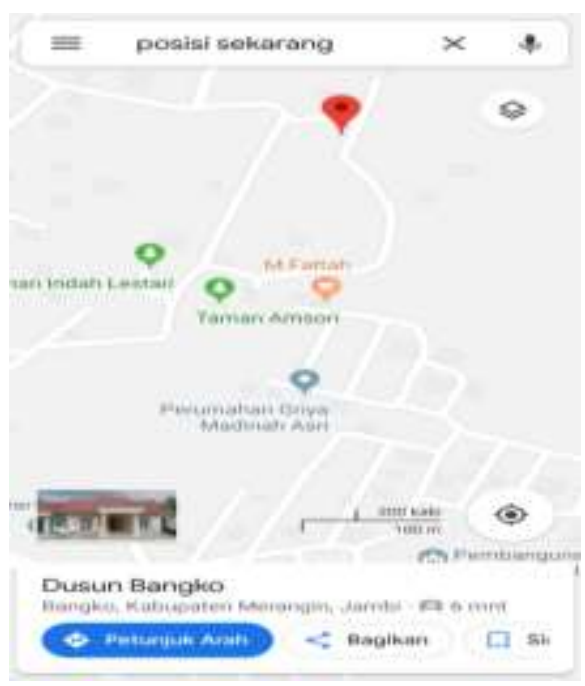

Sampel diambil sebanyak 5 rimpang kunyit kemudian sampel terlebih dahulu dicuci dan dikeringkan sedikit. Kemudian tanaman kunyit dibersihkan dari kulitnya sehingga pada proses pembuatan ekstrak nanti kulit luarnya tidak ikut terparut. 


\section{b. Pembuatan Ekstrak}

Ekstrak dibuat dengan cara memarut kunyit dengan parutan yang telah disiapkan sebanyak 5 rimpang kunyit yang besar di dalam mangkok keramik menambahkan air sebanyak $50 \mathrm{ml}$. Kemudian dilakukan proses penyaringan agar ampas kunyit berpisah dari ekstraknya. Ekstrak yang sudah disaring kemudian dimasukkan ke dalam gelas dan siap untuk diminum

\section{c. Pengujian Ekstrak}

Ekstrak yang sudah jadi diuji sebanyak $50 \mathrm{ml}$ setiap pagi dan malam hari selama jangka waktu 1 bulan . hasil yang diperoleh pada jangka waktu 1 minggu sudah berangsur-angsur sehat tetapi tidak terlalu signifikan atau tidak terlalu nampak. Minggu kedua dan ketiga orang tersebut sudah menunjukkan perubahan yakni dari yang awalnya susah untuk makan menjadi lebih lahap ketika makan. Pada Minggu keempat (terakhir) telah nampak perubahan yang signifikan dari badan si penderita maag tersebut bahwa dia sudah sangat sehat, nafsu makannya semakin bertambah, tidak pernah terasa lagi nyeri di bagian perut (lambung) serta dia sudah bisa kembali beraktivitas seperti semula.

Metode ini dapat dibuat dengan cara diagram alir sebagai berikut :

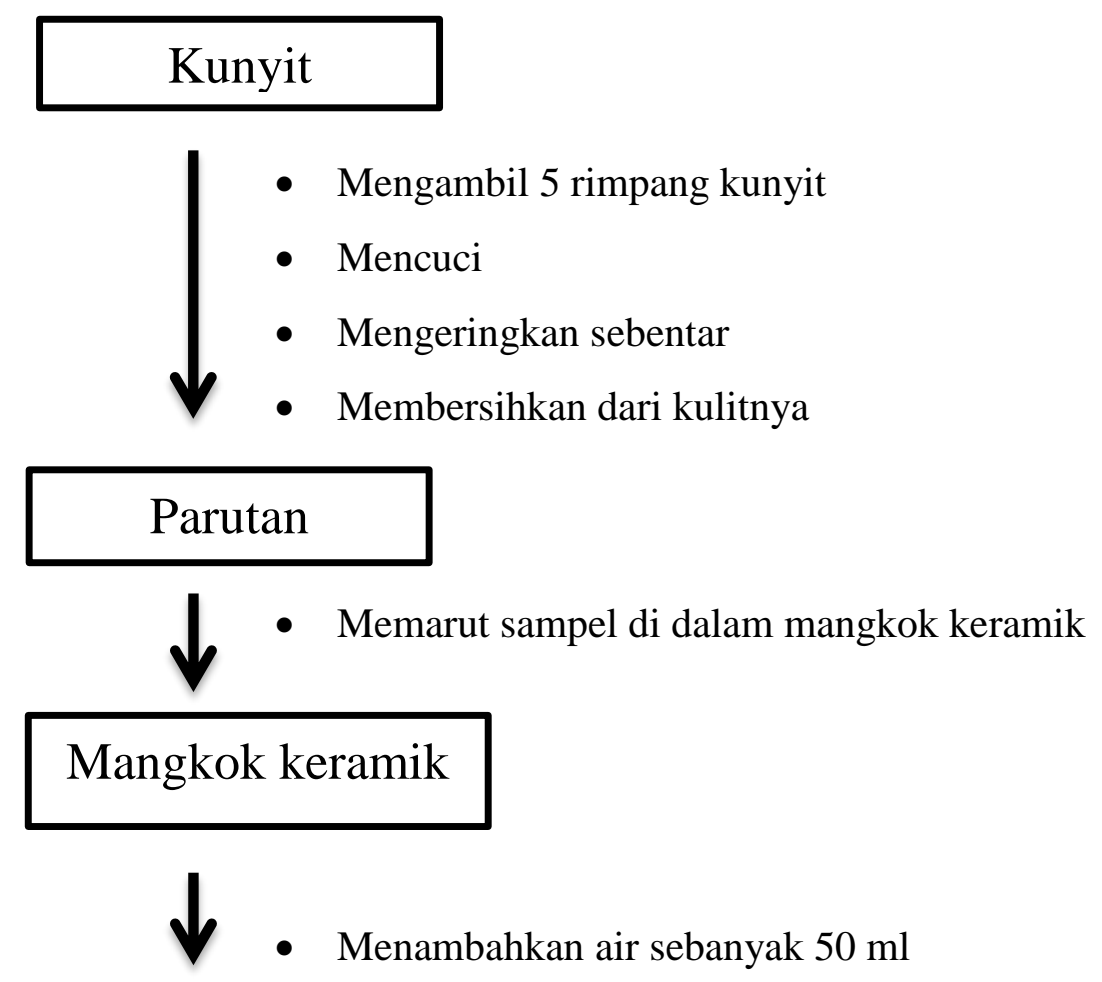




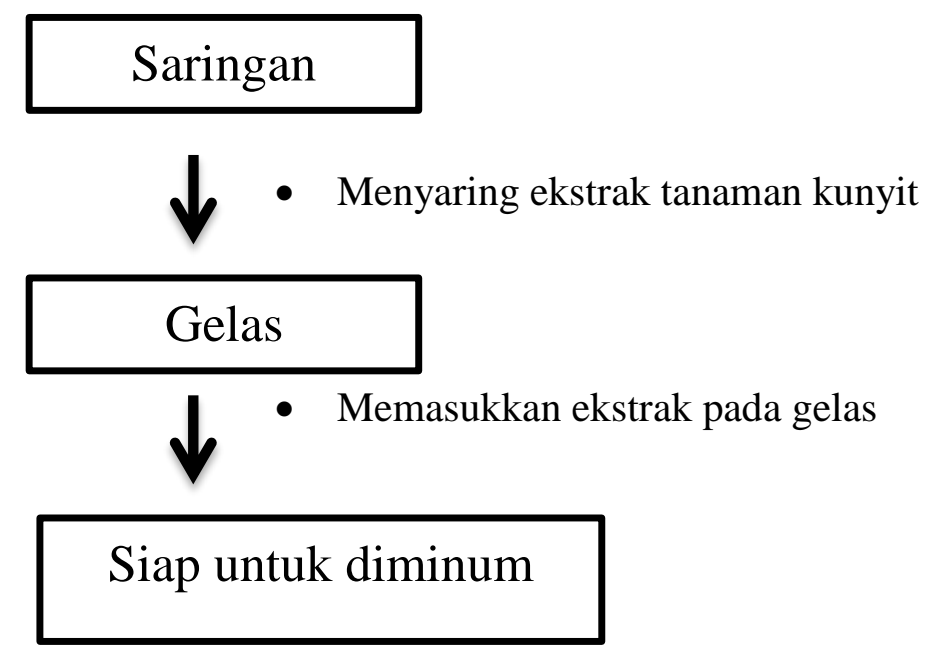

- Mengulangi langkah tersebut setiap hari waktu pagi dan malam dalam jangka waktu 1 bulan

\section{HASIL}

Hasil pembuatan ekstrak diperoleh sebanyak $50 \mathrm{ml}$ dari pembuatan ekstrak tanaman kunyit sebanyak 5 rimpang tanaman kunyit. Hal ini dapat dilihat dari proses pembuatan pada gambar berikut:

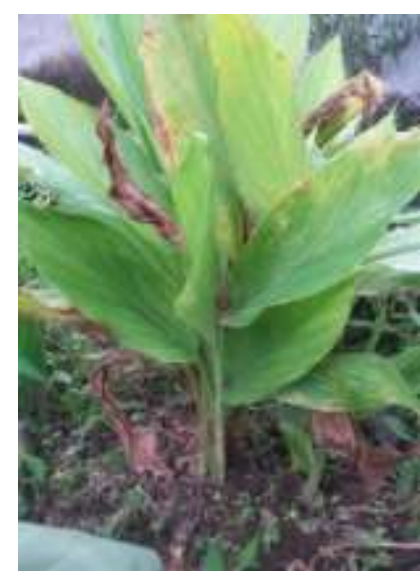

Tanaman kunyit

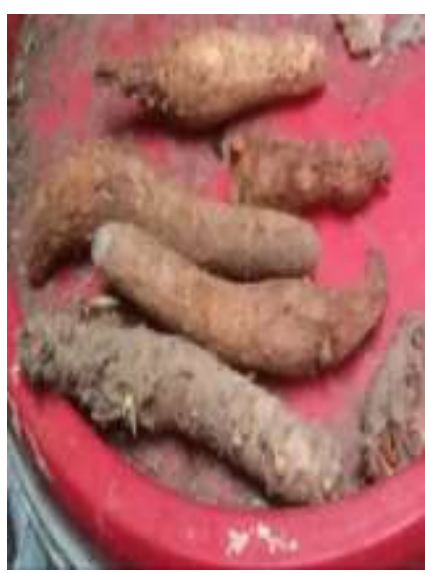

Kunyit yang belum dibersihkan

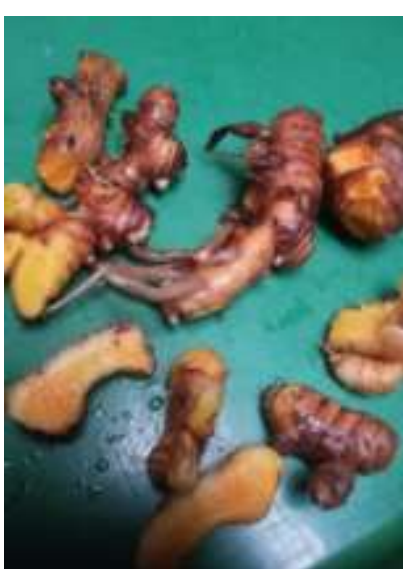

Kunyit yang sudah dibersihkan 


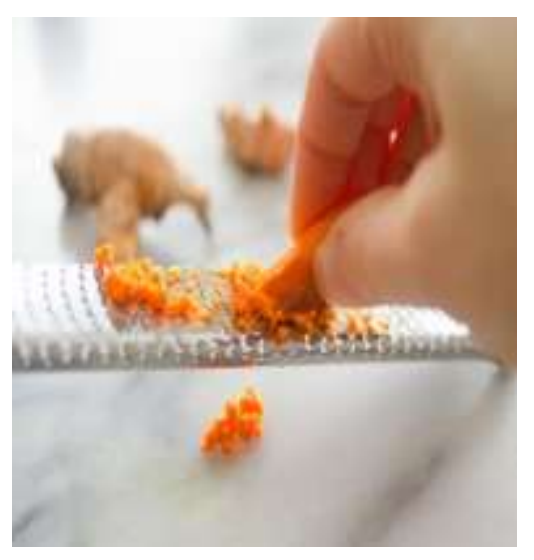

https://blogunik.com/intip-beberapacara-ampuh-menghilangkan-warnagelap-di-ketiak/

Memarut Kunyit

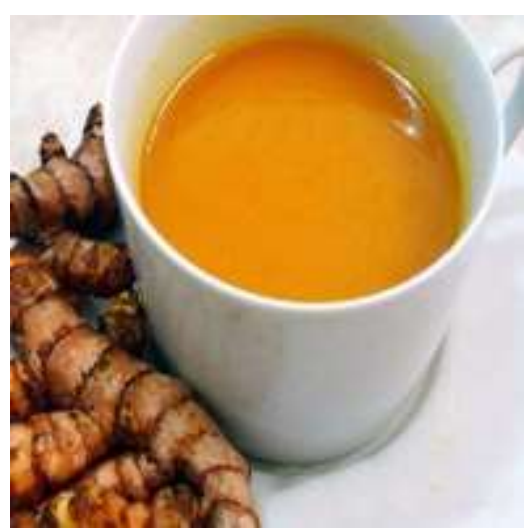

Ekstrak Kunyit + Air $50 \mathrm{ml}$ http://www.lintaskesehatan.com/inimanfaat-berlimpah-minum-jamu-kunyit/

Pengujian dilakukan terhadap seseorang yang menderita penyakit maag dan berhasil menyembuhkan penyakit berdasarkan tabel berikut:

\section{Tabel hasil pengamatan :}

\begin{tabular}{|c|c|c|c|}
\hline No & Perlakuan & Waktu & Hasil \\
\hline 1 & \multirow{4}{*}{$\begin{array}{l}\text { Diminum dua kali sehari } \\
\text { pada saat pagi dan malam } \\
\text { hari setelah makan } \\
\text { sebanyak } 50 \mathrm{ml} \text { selama } \\
\text { jangka waktu sebulan }\end{array}$} & Minggu pertama & $* *$ \\
\hline 2 & & Minggu kedua & $* * *$ \\
\hline 3 & & Minggu ketiga & $* * * *$ \\
\hline 4 & & Minggu keempat & $* * * * *$ \\
\hline
\end{tabular}

Keterangan : 
*** : Lumayan Sembuh

$* * * * \quad:$ Sembuh

***** : Sangat Sembuh

\section{PEMBAHASAN}

Berdasarkan percobaan yang telah dilakukan yaitu tentang kinetika reaksi ${ }^{(121-125)}$ ekstrak kunyit kuning pada penyembuhan penyakit maag yang bertujuan untuk membuktikan pengaruh ekstrak tanaman kunyit dalam menyembuhkan penyakit maag.

Kunyit dalam bahasa latin disebut Curcuma Longa atau Curcuma Domestica Val $^{(126-127)}$. Mempunyai daun yang berwarna hijau dan tinggi tanaman kunyit sekitar $-70 \mathrm{~cm}$. Serta di dalam akarnya ${ }^{(128-130)}$ terdapat kunyit yang akan kita uji. Kunyit memiliki banyak khasiat hal ini dibuktikan dengan telah banyaknya penelitian tentang tanaman kunyit.

\section{Pembuatan}

Proses ini dilakukan dengan cara mengektraksi tanaman kunyit kuning sebanyak 5 rimpang kunyit kuning. Kunyit kuning berfungsi sebagai obat herbal dalam penyembuhan penyakit maag. Kemudian ekstrak tersebut ditambahkan dengan $50 \mathrm{ml}$ air selanjutnya dapat langsung diminum dalam gelas. kegunaan ekstrak kunyit kuning ini sangat banyak terutama pada bidang kesehatan dan kecantikan. Seperti pada bidang kesehatan di mamfaatkan sebagai obat dalam menyembuhkan penyakit maag.

Dalam proses pembuatan ekstrak ditemukan beberapa kendala seperti: sulitnya dicari kunyit kuning ${ }^{(131-135)}$ yang berukuran besar dan warnanya yang kuning pekat sehingga dalam penggunaan ini dipakai kunyit yang sedikit lebih kecil dari yang seharusnya, kendala selanjutnya yaitu pada saat proses memarut tanaman kunyit karena ukuran kunyit yang diperoleh kecil dari yang seharusnya sehingga pada proses memarut kunyit yang seharusnya 
berlangsung cepat menjadi lambat. Karena, diperlukannya ketelitian yang tinggi pada saat memarut kunyit tersebut.

\section{Uji Coba}

Grafik (regresi )hasil dari uji yang dilakukan terhadap tanaman kunyit kuning:

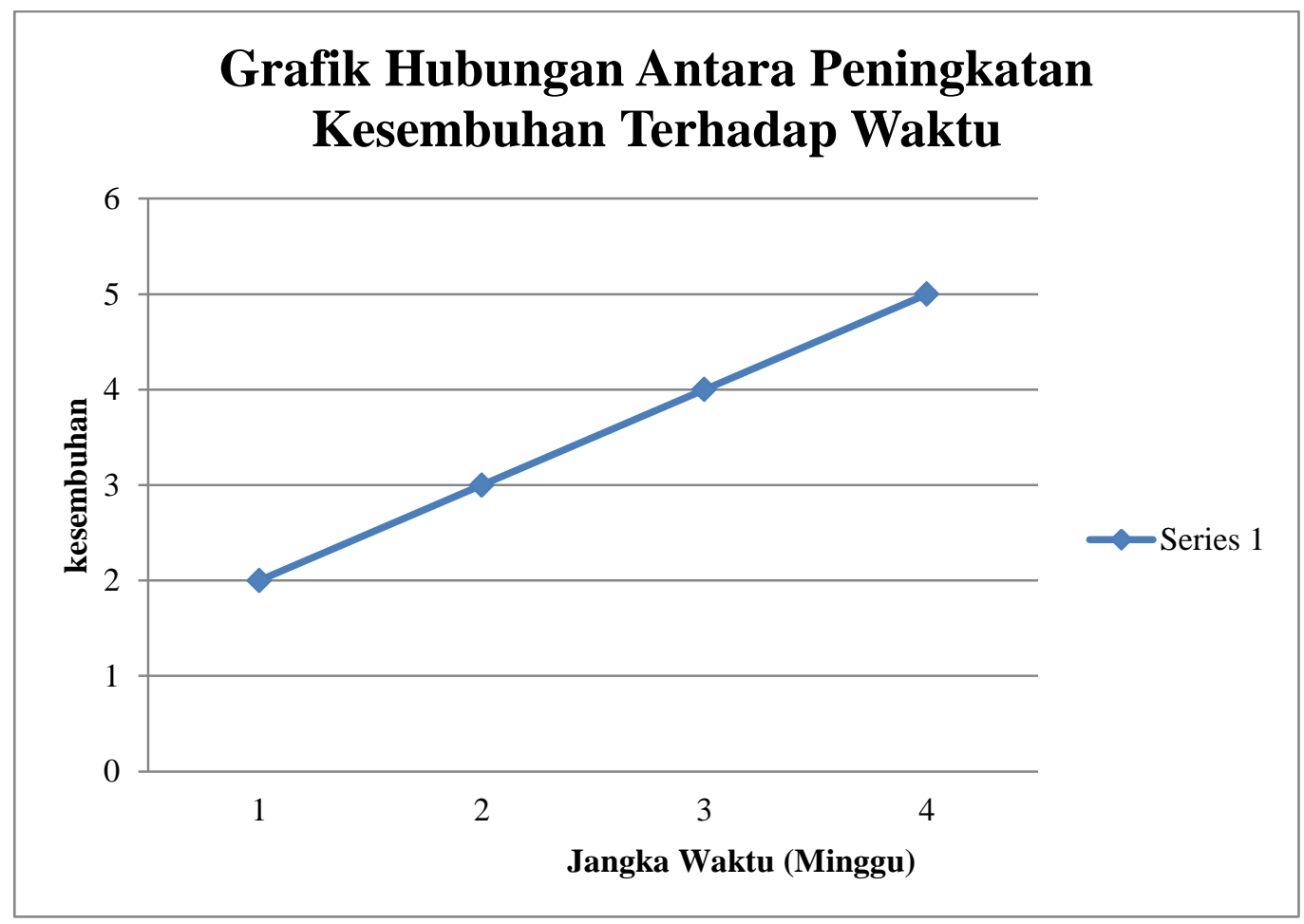

Reaksi ${ }^{(136-140)}$ yang terjadi yaitu antara lambung dengan zat yang terkandung di dalam kunyit yang disebut dengan kurkuminoid. Kurkuminoid $^{(141-143)}$ adalah zat yang bertindak sebagai obat di dalam kunyit di mana kurkuminoid berfungsi untuk melapisi dinding didalam lambung akibat luka serta berfungsi dalam menurunkan kadar asam lambung di dalam lambung tersebut. Kurkuminod ${ }^{(144-146)}$ terdiri atas : kurkumin, demestoksikurkumin dan bisdemetoksikurkumin $^{(147-150)}$. 
Struktur kimia dari kurkuminoid adalah sebagai berikut:

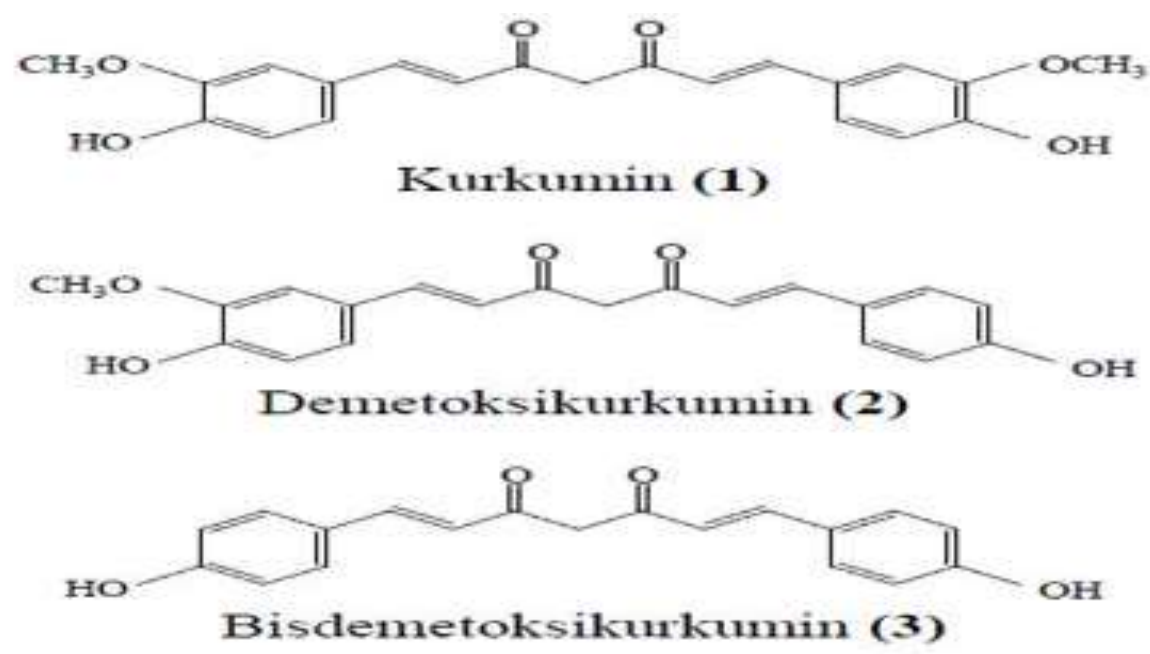

https://hadyherbs.wordpress.com/category/kimia-bahan-alam/kurkumin/

\section{Interaksi}

Dari data diperoleh adanya peningkatan dari kesembuhan penyakit maag dalam jangka waktu 1 bulan. Hal ini disebabkan oleh adanya interaksi dari zat yang terkandung di dalam kunyit yang berperan sebagai obat untuk menghilangkan atau melapisi dinding mukosa lambung dari luka serta menurunkan kadar asam lambung yang terdapat pada lambung. Zat tersebut disebut dengan kurkuminoid..

Peningkatan itu terjadi karena apabila ekstrak kunyit itu dipakai secara teratur dalam jangka waktu yang lama maka akan tampak perubahan atau peningkatan kesembuhan dari orang tersebut. Hal ini dibuktikan dengan uji coba langsung terhadap penderita penyakit maag tersebut yang mana orang tersebut adalah seorang ibu rumah tangga. Sebelum meminum ekstrak tanaman kunyit ini ibu rumah tangga tersebut sudah berulang kali masuk rumah sakit sehingga dokter menyatakan bahwa ibu rumah tangga itu mengidap maag akut. Ketika itu ada salah seorang yang menganjurkan untuk meminum ekstrak tanaman kunyit kuning sebab kunyit kuning bisa menyembuhkan penyakit maag. Kemudian ibu rumah tangga itu mencoba meminum ekstrak tanaman kunyit kuning tersebut selama dalam kurun waktu 1 bulan sebanyak $50 \mathrm{ml}$ 
ekstrak tanaman kunyit pada waktu padi dan malam hari dan seperti yang dikatakan dari awal bahwa ekstrak tanaman kunyit dapat menyembuhkan penyakit maag hal ini juga terjadi pada ibu rumah tangga tersebut di mana dia sekarang sudah tidak lagi menderita penyakit maag akut.

\section{KESIMPULAN}

1. Ekstrak dapat dibuat dari 4 rimpang tanaman kunyit menghasilkan sekitar $50 \mathrm{ml}$ ekstrak tanaman kunyit.

2. Ekstrak dapat menyembuhkan penyakit maag dengan pemakaian 2 kali sehari padi dan malam selama 1 bulan.

3. Ekstrak ini dapat menyembuhkan penyakit maag karena mengandung zat kurkuminoid yang berfungsi sebagai zat yang melapisi atau menyembuhkan luka pada perut karena maag merupakan penyakit pada bagian perut akibat adanya infeksi dari bakteri serta karena adanya luka terbuka yang muncul di lapisan dalam lambung.

\section{REFERENSI}

(1) Mukaromah, Ana Hidayati, Irawan, Bagus,2008. Pemanfaatan Reaktor Membran Fotokatalitik dalam Mendegradasi Fenol dengan Katalisis TiO2 dengan Adanya Ion Logam Fe(III) dan Cu(II). Vol 1, No 1

(2) Altway, Ali, Winardi, Sugeng, Rachimoellah, M,2004.Aplikasi Packet Diffusion Model untuk Menganalisis Pengaruh Fenomena Micromixing terhadap Jalannya Reaksi Kimia Paralel di dalam Reaktor Tangki reraduk Kontinyu dengan Aliran Umpan Terpisah. Vol 28, No 2

(3) Nunung D. Putra, Khaswar Syamsu, Ani Suryani,2004. KAJIAN PENGARUH KONSENTRASI H2SO4 DAN SUHU REAKSI PADA PROSES PRODUKSI SURFAKTAN METIL ESTER SULFONAT (MES) DENGAN METODE SULFONASI.VOL 14,NO 2

(4) Irawan, RM. Bagus,2006. PENGARUH KATALIS TEMBAGA DAN KROM TERHADAP EMISI GAS CARBON MONOKSIDA DAN HIDRO CARBON PADA KENDARAAN MOTOR BENSIN.Vol 4,No 1

(5) al Hakimi, Nurush Shofi, Hanapi, Ahmand, Fasya, Ahmad Ghanaim,2017.Green Synthesis Senyawa Imina dari Vanillin and Anilina dengan Katalis Alami Air Jeruk Nipis (Citrus aurantifolia). Vol 5, No 4 
(6) Abdullah, Jaya, Jaka Darma, Rodiansono,2010. Optimasi Jumlah Katalis KOH dan $\mathrm{NaOH}$ pada Pembuatan Biodiesel dari Minyak Kelapa Sawit Menggunakan Kopelarut. Vol 4, No 1

(7) Mambang, D. Elysa Putri, Rosidah, -, Suryanto, Dwi,2014. AKTIVITAS ANTIBAKTERI EKSTRAK TEMPE TERHADAP BAKTERI Bacillus subtilis DAN Staphylococcus aureus [Antibacterial Activity of Tempe Extracts on Bacillus subtilis and Staphylococcus aureus]. Vol 25, No 1

(8) Soemardi, Eddy, Utami, Pri Iswati, Wakhid, Abdul,2003. UJI ANTI BAKTERI EKSTRAK AIR KUNYIT (Curcuma domestica, Val.) TERHADAP BAKTERI Pseudomonas aeruginosa PADA IKAN GURAMI (Osphronemus gouramy. Lac). Vol 1, No 1

(9) Wardhani, Ratih Pramita, Ningsih, Rini Rahayu, Ramadhona, Rika, Astuti, Hutari Puji, Fitriyani, Noor,2013. TEH BIJI SEMANGKA (CITRULLUS LANATUS) SEBAGAI OBAT HERBAL ALTERNATIF JANTUNG DAN ANTI KANKER. Vol. 4 No. 2

(10) S, Gunanati, Priosoeryanto,Bambang Pontjo, Wientarsih, Ietje, Sumarny, Ros,2009. Pengobatan penyakit tumor mammae melalaui operasi (matektomi dan ovariohisterektomi) dan kombinasinya (tanaman herbal) pada hewan. Vol 14, No 1

(11) Rizki Saputra, M. and Sumarmin, R. (2018) "PENGARUH EKSTRAK DAUN SIRIH MERAH (Piper crocatum Ruiz \& Pav.) TERHADAP GLUKOSA DARAH MENCIT (Mus musculus L.) JANTAN YANG DIINDUKSI SUKROSA”, EKSAKTA: Berkala Ilmiah Bidang MIPA, 19(1), pp. 43-55. doi: 10.24036/eksakta/vol19-iss 1/124.

(12) Azhar, M., Ahda, Y., Ihsanawati, I., Puspasari, F., Mawarni, S., Risa, B. and Natalia, D. (2017) "SKRINING BAKTERI PENDEGRADASI INULIN DARI RIZOSFER UMBI DAHLIA MENGGUNAKAN INULIN UMBI DAHLIA”, EKSAKTA: Berkala Ilmiah Bidang MIPA, 18(02), pp. 13-20. doi: 10.24036/eksakta/vol18-iss02/44.

(13) Sanjaya, H. (2017) "DEGRADASI METHYLENE BLUE MENGGUNAKAN KATALIS ZnO-PEG DENGAN METODE FOTOSONOLISIS”, EKSAKTA: Berkala Ilmiah Bidang MIPA, 18(02), pp. 21-29. doi: 10.24036/eksakta/vol18-iss02/45.

(14) Sari, A. (2017) "POTENSI ANTIOKSIDAN ALAMI PADA EKSTRAK DAUN JAMBLANG (Syzigium cumini (L.) Skeels)”, EKSAKTA: Berkala 
Ilmiah Bidang MIPA, 18(02), pp. 107-112. doi: 10.24036/eksakta/vol18iss $02 / 61$.

(15) Tutuarima, T. (2017) "SIFAT FISIK DAN KIMIA MARMALADE JERUK KALAMANSI (Citrus microcarpa) : KAJIAN KONSENTRASI PEKTIN DAN SUKROSA Physical and Chemical Properties of Marmalade Citrus of Calamondin (Citrus microcarpa) : Study of Pectin and Sucrose Concentrations", EKSAKTA: Berkala Ilmiah Bidang MIPA, 18(02), pp. 164172. doi: 10.24036/eksakta/vol18-iss02/73.

(16) Horiza, H., Azhar, M. and Efendi, J. (2017) "EKSTRAKSI DAN KARAKTERISASI INULIN DARI UMBI DAHLIA (Dahlia sp.L) SEGAR DAN DISIMPAN", EKSAKTA: Berkala Ilmiah Bidang MIPA, 18(01), pp. 31-39. doi: 10.24036/eksakta/vol18-iss01/14.

(17) Iryani, I., Iswendi, I. and Katrina, I. T. (2017) "UJI AKTIVITAS ANTI DIABETES MELLITUS SENYAWA METABOLIT SEKUNDER FRAKSI AIR DARI BERAS KETAN HITAM ( Oryza satival. Var glutinosa) PADA MENCIT PUTIH", EKSAKTA: Berkala Ilmiah Bidang MIPA, 18(01), pp. 54-60. doi: 10.24036/eksakta/vol18-iss01/17.

(18) Huda, N. (2017) "PENGARUH EKSTRAK SAMBILOTO (Andrographis paniculata Nees.) TERHADAP SIKLUS ESTRUS MENCIT (Mus musculus L. Swiss Webster)", EKSAKTA: Berkala Ilmiah Bidang MIPA, 18(02), pp. 69-76. doi: 10.24036/eksakta/vol18-iss02/55.

(19) Mulia, M. (2017) "ISOLASI KUMARIN DARI KULIT BUAH LIMAU SUNDAI (Citrus nobilis Lour)", EKSAKTA: Berkala Ilmiah Bidang MIPA, 18(02), pp. 137-145. doi: 10.24036/eksakta/vol18-iss02/70.

(20) Sumarmin, R. (2018) "Pengaruh Ekstrak Kulit Buah Manggis (Garcinia mangostana L.) terhadap Histologis Pankreas Mencit (Mus musculus L. Swiss Webster) yang Diinduksi Sukrosa", EKSAKTA: Berkala Ilmiah Bidang MIPA, 19(1), pp. 100-112. doi: 10.24036/eksakta/vol19-iss1/123.

(21) Putri, D., Fifendy, M. and putri, M. (2018) "DIVERSITAS BAKTERI ENDOFIT PADA DAUN MUDA DAN TUA TUMBUHAN ANDALEH (Morus macroura miq.)", EKSAKTA: Berkala Ilmiah Bidang MIPA, 19(1), pp. 125-130. doi: 10.24036/eksakta/vol19-iss1/122.

(22) Dinata, M. and Soehardi, F. (2018) "Factor Analysis of Physics Chemistry Waters that Affects Damage Safety Cliff on the Outskirts of River Siak", EKSAKTA: Berkala Ilmiah Bidang MIPA, 19(2), pp. 46-49. doi: 10.24036/eksakta/vol19-iss2/143. 
(23) Iskandar, I., Horiza, H. and Fauzi, N. (2017) "EFEKTIVITAS BUBUK BIJI PEPAYA (Carica Papaya Linnaeaus) SEBAGAI LARVASIDA ALAMI TERHADAP KEMATIAN LARVA AEDES AEGYPTY TAHUN 2015", EKSAKTA: Berkala Ilmiah Bidang MIPA, 18(01), pp. 12-18. doi: 10.24036/eksakta/vol18-iss01/12.

(24) Santoso, B. (2018) "IDENTIFIKASI AKUIFER MENGGUNAKAN METODE GEOLISTRIK RESISTIVITAS DI DAERAH BEBANDEM, KARANG ASEM, BALI", EKSAKTA: Berkala Ilmiah Bidang MIPA, 19(1), pp. 24-34. doi: 10.24036/eksakta/vol19-iss 1/101.

(25) Prihatini, R. (2017) "PEMANFAATAN AIR KELAPA UNTUK MENINGKATKAN PERTUMBUHAN AKAR STEK TUNAS AKSILAR Andrographis paniculata Nees", EKSAKTA: Berkala Ilmiah Bidang MIPA, 18(02), pp. 62-68. doi: 10.24036/eksakta/vol18-iss02/54.

${ }^{(26)}$ Febriani, S. S., Yolanda, T., Arianti, V. A., \& Zainul, R. (2018, October 12). A Review Solid Stated : Principles and Methode. https://doi.org/10.31227/osf.io/7us4x

${ }^{(27)}$ Liza, Y. M., Yasin, R. C., Maidani, S. S., \& Zainul, R. (2018, October 9). SOL GEL : PRINCIPLE AND TECHNIQUE (A REVIEW). https://doi.org/10.31227/osf.io/2cuh8

${ }^{(28)}$ Dinata, A. A., Rosyadi, A. M., Hamid, S., \& Zainul, R. (2018, October 15). A Review CHEMICAL VAPOR DEPOSITION : PROCESS AND APPLICATION. https://doi.org/10.31227/osf.io/yfeau

(29) Zainul, R. (2018, August 16). Design and Modification of Copper Oxide Electrodes for Improving Conversion Coefficient Indoors Lights (PV-Cell) Photocells. https://doi.org/10.31227/osf.io/pgn84

(30) Zainul, R., Effendi, J., \& M. (2018, December 10). Phototransformation of Linear Alkylbenzene Sulphonate (LAS) Surfactant Using ZnO-CuO Composite Photocatalyst. https://doi.org/10.31227/osf.io/fec28

(31) Husna, H., \& Zainul, R. (2019, February 3). A Review : Aspek Termodinamika LiNO3 dalam Larutannya. https://doi.org/10.31227/osf.io/45mbd

(32) Zainul, R. (2018, August 16). Determination of the half-life and the quantum yield of $\mathrm{ZnO}$ semiconductor photocatalyst in humic acid. https://doi.org/10.31227/osf.io/e8a9x 
${ }^{(33)}$ Putri, D. F., Ritonga, H. M., Murdiati, V., \& Zainul, R. (2018, October 15). A REVIEW https://doi.org/10.31227/osf.io/dm56c

(34) Zainul, R., \& Prima, C. B. (2018, November 11). Desain Geometri Sel PV. https://doi.org/10.31227/osf.io/7n8t4

(35) Nurfadilah, K. K., \& Zainul, R. (2019, February 3). Kalium Nitrat (KNO3): Karakteristik Senyawa dan Transpor Ion.https://doi.org/10.31227/osf.io/dr8ef

(36) Yuliani, F., \& Zainul, R. (2018, November 13). Analisis Termodinamika Molekul Magnesium Sulphate (MgSO4). https://doi.org/10.31227/osf.io/uxz4y

(37) Alfionita, T., \& Zainul, R. (2019, January 29). Calcium Chloride (CaCl2) : Characteristics and Molecular Interaction in Solution. https://doi.org/10.31227/osf.io/m37xj

(38) Zainul, R., \& Prima, C. B. (2018, November 11). Desain Geometri Sel PV. https://doi.org/10.31227/osf.io/7n8t4

(39) Feronika, N. I., \& Zainul, R. (2018, November 19). Kalium Permanganat: Termodinamika Mengenai Transport Ionik dalam Air. https://doi.org/10.31227/osf.io/g6eyk

(40) Lubis, A. P., \& Zainul, R. (2018, November 5). Interaksi Molekuler Amonium Hidroksida. https://doi.org/10.31227/osf.io/jht3b

(41) chaidir, z., Fadjria, N., A., \& Zainul, R. (2018, August 11). ISOLATION AND MOLECULAR IDENTIFICATION OF FRESHWATER MICROALGAE IN MANINJAU LAKE WEST SUMATERA. https://doi.org/10.31227/osf.io/nbcuf

(42) Anhar, A., Sumarmin, R., \& Zainul, R. (2018, August 11). Measurement of Glycemic Index of West Sumatera Local Rice Genotypes for Healthy Food Selection. https://doi.org/10.31227/osf.io/tgy8h

(43) Artika, P. I., \& Zainul, R. (2018, November 19). Potassium Bromide (KBr): Transformasi ionik dan sifat temodinamika dalam Larutan. https://doi.org/10.31227/osf.io/a5hyz

(44) Hakimi, A., \& Zainul, R. (2019, January 31). Asam Arsenat (H3AsO4) : Analisis Molekular dan Karakteristik Senyawa. https://doi.org/10.31227/osf.io/e486z 
(45) Warlinda, Y. A., \& Zainul, R. (2019, January 29). Asam Posfat (H3PO4): Ionic Transformation of Phosphoric Acid in Aqueous Solution. https://doi.org/10.31227/osf.io/s3y8v

(46) Sari, E. S. J., \& Zainul, R. (2019, January 31). Nitrogen Triflorida (NF3) : Termodinamika dan Transpor Elektron NF3. https://doi.org/10.31227/osf.io/3nzrh

(47) Jumalia, R., \& Zainul, R. (2019, February 3). Natrium Karbonat : Termodinamika dan Transport Ion. https://doi.org/10.31227/osf.io/y2vq9

(48) Sari, M., \& Zainul, R. (2018, November 19). Kalium Dikromat (K2Cr2O7) Spektroskopi dan Transpor K2Cr2O7. https://doi.org/10.31227/osf.io/w92je

(49) Dwynda, I., \& Zainul, R. (2018, November 19). Boric Acid (H3 (BO3): Recognize The Molecular Interactions in Solutions. https://doi.org/10.31227/osf.io/6wead

${ }^{(50)}$ Shafitri, M., \& Zainul, R. (2019, February 3). Vanadium Pentaoksida (V2O5) : Termodinamika Molecular dan Interaksi Ion dalam Larutan. https://doi.org/10.31227/osf.io/jgmvd

(51) Delvi, I. P., \& Zainul, R. (2019, February 3). Mercury (II) Nitrate (Hg (NO3)2): Interaksi Molekul dan Adsorpsi $\mathrm{Hg}$ dengan Karbon Aktif. https://doi.org/10.31227/osf.io/eqyax

(52) Kristy, D. P., \& Zainul, R. (2019, February 3). Analisis Molekular dan Transpor Ion Natrium Silikat. https://doi.org/10.31227/osf.io/8ac4m

(53) Yanti, C. F., \& Zainul, R. (2018, December 2). A Review Ba (OH)2 : Transpor Ionik pada Barium Hidroksida di dalam Air dengan Konsep Termodinamika. https://doi.org/10.31227/osf.io/fsbq3

(54) Zainul, R. (2018, December 24). Prototype Reaktor Deksagonal. https://doi.org/10.31227/osf.io/d7wzk

${ }^{(55)}$ P, O. M., A, L. G., S, A. Y. M., \& Zainul, R. (2018, October 12). A Review Grinding : Teknik dan Prinsip Dasar pada Pengolahan Material. https://doi.org/10.31227/osf.io/trv4q

(56) Husna, A. D., \& Zainul, R. (2019, February 4). Analisis Molekular dan Karakteristik Hidrogen Sianida (HCN). https://doi.org/10.31227/osf.io/7xej9

(57) Yulis, R., Zainul, R., \& M. (2018, December 10). DESAIN DAN KARAKTERISASI SEL SURYA SISTEM ELEKTRODA TEMBAGA (I) 
OKSIDA $(\mathrm{Cu} 2 \mathrm{O} / \mathrm{Al})$ MODEL PIPA PADA LARUTAN NATRIUM SULFAT (Na2SO4). https://doi.org/10.31227/osf.io/m43js

(58) Y., \& Zainul, R. (2018, November 18). SILVER SULFATE (Ag2SO4): MOLECULAR ANALYSIS AND ION TRANSPORT. https://doi.org/10.31227/osf.io/n8g9k

(59) M., Sanjaya, H., \& Zainul, R. (2018, August 11). Characterization of napa soil and adsorption of $\mathrm{Pb}$ (II) from aqueous solutions using on column method. https://doi.org/10.31227/osf.io/t8fh9

(60) Husna, H., \& Zainul, R. (2019, February 3). A Review : Aspek Termodinamika LiNO3 dalam Larutannya. https://doi.org/10.31227/osf.io/45mbd

(61) Putri, G. E., Arief, S., Jamarun, N., Gusti, F. R., \& Zainul, R. (2018, December 10). Microstuctural Analysis and Optical Properties of Nanocrystalline Cerium Oxides Synthesized by Precipitation Method. https://doi.org/10.31227/osf.io/qcz4y

${ }^{(62)}$ Rahmadhanty, S., \& Zainul, R. (2018, December 24). DESIGN OF HUMAT ACID SOLID SOLUTION REACTOR THROUGH PHOTOTRANSFORMATION OF COPPER OXIDE (CuO) SEMICONDUCTOR PLATE. https://doi.org/10.31227/osf.io/yhd9x

(63) Zainul, R., Alif, A., Aziz, H., Arief, S., \& s. (2018, August 16). Photoelectrosplitting Water Mechanism at Carbon Electrode Surface using Indoor lights. https://doi.org/10.31227/osf.io/vcxq8

(64) Zainul, R., \& Prima, C. B. (2018, December 9). TEKNOLOGI MATERIAL MAJU Prinsip Dasar dan Aspek Rekayasa. https://doi.org/10.31227/osf.io/p63wc

(65) Zainul, R. (2018, August 16). Design and Modification of Copper Oxide Electrodes for Improving Conversion Coefficient Indoors Lights (PV-Cell) Photocells. https://doi.org/10.31227/osf.io/pgn84

(66) Yanuar, F., Tillah, M. and Devianto, D. (2018) "Modeling of Human Development Index Using Ridge Regression Method”, EKSAKTA: Berkala Ilmiah Bidang MIPA, 19(2), pp. 1-11. doi: 10.24036/eksakta/vol19-iss2/134.

(67) Enjelina, W., Mansyurdin, M. and Meideliza, T. (2018) "Analysis of Nepenthes Hybrids in Bukik Taratak West Sumatra by RAPD 
Technique", EKSAKTA: Berkala Ilmiah Bidang MIPA, 19(2), pp. 12-20. doi: 10.24036/eksakta/vol19-iss2/137.

${ }^{(68)}$ Syafei, N., Hidayat, D., Emilliano, E. and Men, L. (2018) “Analysis Cracking Corrosion on Carbon Steel Pipes API 5L-X65 In Solution $7700 \mathrm{ml}$ Aquades, $250 \mathrm{ml}$ Acetic Acid and $50 \mathrm{ml}$ Ammonia with Gas CO2 and $\mathrm{H} 2 \mathrm{~S}$ in Saturation Condition", EKSAKTA: Berkala Ilmiah Bidang MIPA, 19(2), pp. 21-31. doi: 10.24036/eksakta/vol19-iss2/138.

${ }^{(69)}$ Parbuntari, H., Prestica, Y., Gunawan, R., Nurman, M. and Adella, F. (2018) "Preliminary Phytochemical Screening (Qualitative Analysis) of Cacao Leaves (Theobroma cacao L.)", EKSAKTA: Berkala Ilmiah Bidang MIPA, 19(2), pp. 40-45. doi: 10.24036/eksakta/vol19-iss2/142.

(71) Harahap, F. and Lubis, L. (2018) “Analysis of Heavy Metals Distribution in the River Town of Hamasaki's Rod Padang sidimpuan”, EKSAKTA: Berkala Ilmiah Bidang MIPA, 19(2), pp. 50-56. doi: 10.24036/eksakta/vol19iss $2 / 149$.

(72) Sofyanita, S. and Octaria, Z. (2018) "Fenthion Compound Degradation in the Pesticide Bayleton $500 \mathrm{ec}$ in Sonolysis, Ozonolysis and Sonozolysis with Addition of TiO2-anatase”, EKSAKTA: Berkala Ilmiah Bidang MIPA, 19(2), pp. 70-79. doi: 10.24036/eksakta/vol19-iss2/153.

(73) Vauzia, V. and Gusmira, E. (2018) "The Response of Jabon Seeds Germination (Anthocephalus cadamba (Roxb.)Miq.) against the Duration of Combustion and Illumination", EKSAKTA: Berkala Ilmiah Bidang MIPA, 19(2), pp. 80-87. doi: 10.24036/eksakta/vol19-iss2/154.

(74) Horiza, H. (2018) "The influence of the use of activated carbon Fibres of the cane Against the drop in Salinity In the well Dig In RT 003 RW 006 Village Cape Town Unggat Tanjungpinang Year 2017”, EKSAKTA: Berkala Ilmiah Bidang MIPA, 19(1), pp. 1-6. doi: 10.24036/eksakta/vol19-iss1/97.

(75) Syafei, N. (2018) "Riset Material ANALISA FENOMENA KOROSI PELAT PIPA BAJA KARBON API 5L-X65 DALAM LARUTAN 7900 ML AIR LAUT DAN 100 ML AMONIAK PADA KONDISI GAS CO2 DAN H2S JENUH PADA SUHU RUANG.", EKSAKTA: Berkala Ilmiah Bidang MIPA, 19(1), pp. 7-13. doi: 10.24036/eksakta/vol19-iss1/83.

(76) Ruswandi, R. (2018) "Determination of Fructose Content resulted by Inulin Hydrolysis with DNS as Oxidizer”, EKSAKTA: Berkala Ilmiah Bidang MIPA, 19(1), pp. 14-23. doi: 10.24036/eksakta/vol19-iss 1/102. 
(77) Hidayani, T. (2018) "GRAFTING POLIPROPILENA DENGAN MALEAT ANHIDRIDA SEBAGAI PENGIKAT SILANG DENGAN INISIATOR BENZOIL PEROKSIDA”, EKSAKTA: Berkala Ilmiah Bidang MIPA, 19(1), pp. 56-62. doi: 10.24036/eksakta/vol19-iss 1/127.

(78) Advinda, L. (2018) "PERTUMBUHAN STEK HORIZONTAL BATANG JARAK PAGAR (Jatropha curcas L.) YANG DIINTRODUKSI DENGAN PSEUDOMONAD FLUORESEN", EKSAKTA: Berkala Ilmiah Bidang MIPA, 19(1), pp. 68-75. doi: 10.24036/eksakta/vol19-iss1/129.

(79) Chatri, M., Mansyurdin, M., Bakhtiar, A. and Adnadi, P. (2017) "PERBANDINGAN KOMPONEN MINYAK ATSIRI ANTARA DAUN MUDA DAN DAUN DEWASA PADA HYPTIS SUAVEOLENS (L.)POIT", EKSAKTA: Berkala Ilmiah Bidang MIPA, 18(02), pp. 1-12. doi: 10.24036/eksakta/vol18-iss02/41.

${ }^{(80)}$ Samah, S. (2017) “KARAKTERISASI PLASTIK BIODEGRADABEL DARI LDPE-g-MA DAN PATI TANDAN KOSONG SAWIT”, EKSAKTA: Berkala Ilmiah Bidang MIPA, 18(02), pp. 30-38. doi: 10.24036/eksakta/vol18-iss02/48.

(81) Ningsih, S. K. (2017) "SINTESIS DAN KARAKTERISASI NANOPARTIKEL ZnO DOPED Cu2+ MELALUI METODA SOLGEL", EKSAKTA: Berkala Ilmiah Bidang MIPA, 18(02), pp. 39-51. doi: 10.24036/eksakta/vol18-iss02/51.

(82) Saiya, A. (2017) “ANALISIS RESIDU KLORPIRIFOS DALAM SAYURAN KUBIS DENGAN METODE HPLC DI BEBERAPA PASAR TRADISIONAL DI SULAWESI UTARA”, EKSAKTA: Berkala Ilmiah Bidang MIPA, 18(02), pp. 77-85. doi: 10.24036/eksakta/vol18-iss02/57.

(83) Rahmi H.G, I. (2017) “TELAAH FAKTOR-FAKTOR YANG MEMPENGARUHI STATUS GIZI BALITA DI KOTA PADANG BERDASARKAN BERAT BADAN PER TINGGI BADAN MENGGUNAKAN METODE CART", EKSAKTA: Berkala Ilmiah Bidang MIPA, 18(02), pp. 86-99. doi: 10.24036/eksakta/vol18-iss02/59.

(84) Syafei, N. (2017) “ANALISA FENOMENA KOROSI PELAT PIPA BAJA KARBON API 5L-X65 DALAM LARUTAN 250 ML ASAM ASETAT DAN 4750 ML AQUADES PADA KONDISI GAS CO2 DAN H2S JENUH PADA SUHU RUANG", EKSAKTA: Berkala Ilmiah Bidang MIPA, 18(02), pp. 113-120. doi: 10.24036/eksakta/vol18-iss02/63. 
(85) Sudrajat, R. (2017) "TINJAUAN TENTANG KETERKAITAN PARAMETER DENGAN MODEL REGRESI MULTIVARIAT PADA KOLAM IKAN TERTUTUP”, EKSAKTA: Berkala Ilmiah Bidang MIPA, 18(02), pp. 158-163. doi: 10.24036/eksakta/vol18-iss02/72.

(86) Setianto, S. (2017) "ANALISA KUANTITATIF CAMPURAN SENYAWA OKSIDA SEBAGAI DASAR IDENTIFIKASI KANDUNGAN BAHAN SUMBER DAYA ALAM Studi Kasus : Kandungan Mineral pada Pasir Besi di Pesisir Pantai Selatan, Jawa Barat”, EKSAKTA: Berkala Ilmiah Bidang MIPA, 18(02), pp. 173-177. doi: 10.24036/eksakta/vol18-iss02/74.

(87) Hidayat, D. (2017) “IMPLEMENTASI PENGONTROL PID PADA MODEL FISIS ELEKTRONIK”, EKSAKTA: Berkala Ilmiah Bidang MIPA, 18(02), pp. 178-185. doi: 10.24036/eksakta/vol18-iss02/75.

(88) Nasir, M. (2017) "PENGARUH WAKTU HIGH ENERGY MILLING TERHADAP KARAKTERISTIK NANOKAOLIN CAPKALA ASAL KALIMANTAN BARAT", EKSAKTA: Berkala Ilmiah Bidang MIPA, 18(02), pp. 200-209. doi: 10.24036/eksakta/vol18-iss02/78.

(89) Amananti, W. (2017) “ANALISIS MIKROSTRUKTUR LAPISAN TIPIS TiO2:ZnO YANG DIDEPOSISIKAN DIATAS SUBTRAT KACA DENGAN METODE SPRAY COATING UNTUK DEGRADASI LIMBAH ZAT WARNA", EKSAKTA: Berkala Ilmiah Bidang MIPA, 18(02), pp. 210215. doi: 10.24036/eksakta/vol18-iss02/81.

(90) Amir, H., Akmam, A., Bavitra, B. and Azhari, M. (2017) "PENENTUAN KEDALAMAN BATUAN DASAR MENGGUNAKAN METODE GEOLISTRIK TAHANAN JENIS DENGAN MEMBANDINGKAN KONFIGURASI DIPOLE-DIPOLE DAN WENNER DI BUKIT APIT PUHUN KECAMATAN GUGUK PANJANG KOTA BUKITTINGGI", EKSAKTA: Berkala Ilmiah Bidang MIPA, 18(01), pp. 1930. doi: 10.24036/eksakta/vol18-iss01/13.

(91) Ramli, R., Jonuarti, R. and Hartono, A. (2017) “ANALISIS STRUKTUR NANO DARI LAPISAN TIPIS COBALT FERRITE YANG DIPREPARASI DENGAN METODE SPUTTERING”, EKSAKTA: Berkala Ilmiah Bidang MIPA, 18(01), pp. 46-53. doi: 10.24036/eksakta/vol18-iss01/16.

${ }^{(92)}$ Handayani, D. (2017) "KARAKTERISTIK CENDAWAN DARK SEPTATE ENDOPHYTE (DSE) PADA AKAR TANAMAN JAGUNG DAN PADI", EKSAKTA: Berkala Ilmiah Bidang MIPA, 18(01), pp. 61-68. doi: 10.24036/eksakta/vol18-iss01/20. 
(93) Suryelita, S., Etika, S. B. and Kurnia, N. S. (2017) "ISOLASI DAN KARAKTERISASI SENYAWA STEROID DARI DAUN CEMARA NATAL (Cupressus funebris Endl.)", EKSAKTA: Berkala Ilmiah Bidang MIPA, 18(01), pp. 86-94. doi: 10.24036/eksakta/vol18-iss01/23.

(94) Azhar, M., Ahda, Y., Ihsanawati, I., Puspasari, F., Mawarni, S., Risa, B. and Natalia, D. (2017) "SKRINING BAKTERI PENDEGRADASI INULIN DARI RIZOSFER UMBI DAHLIA MENGGUNAKAN INULIN UMBI DAHLIA", EKSAKTA: Berkala Ilmiah Bidang MIPA, 18(02), pp. 13-20. doi: 10.24036/eksakta/vol18-iss02/44.

(95) Joebaedi, K. (2018) "MODEL STAR(1;1) PADA DATA PRODUKTIVITAS TEH”, EKSAKTA: Berkala Ilmiah Bidang MIPA, 19(1), pp. 35-38. doi: 10.24036/eksakta/vol19-iss 1/118.

(96) Maryudi, Maryudi, Hisyam, Anwaruddin,2013. KINETIKA REAKSI KHROM DAN KAPUR PADAM PADA PENGOLAHAN LIMBAH PENYAMAKAN KULIT SECARA BATCH. Vol 11, No 1

(97) Aritonang, Henry F, Tangkuman, Herling D. 2009. REAKSI ESTERIFIKASI GARAM ASAM LEMAK DENGAN ALKIL KLORIDA BERANTAI PANJANG MENGGUNAKAN TRIDODEKILAMIN HIDROKLORIDA SEBAGAI KATALIS PERPINDAHAN DUA FASA. Vol 2, No 1

(98) Kusnaryo, Radya Purna Wijaya, Ali Altway,2011. ANALISA TRANSFER MASSA DISERTAI REAKSI KIMIA ABSORPSI CO2. Vol 6, No 1

(99) Zuhrina Masyithah, Jojor Rohana Oppusunggu, Vinta Rutliana Siregar,2015.PENGARUH JENIS PELARUT DAN TEMPERATUR REAKSI PADA SINTESIS SURFAKTAN DARI ASAM OLEAT DAN nMETIL GLUKAMINA DENGAN KATALIS KIMIA. Vol 4, No 1

(101) Irawan, RM Bagus. 2010. EFEKTIFITAS KATALIS MATERIAL SUBSTRAT PADUAN CuZn (KUNINGAN) DALAM MEREDUKSI EMISI GAS KARBON MONOKSIDA MOTOR BENSIN. Vol 10, No 2

(102) Widayat, Widayat, Sadikky DP, A., Anggraeni, H.2012. PROSES PRODUKSI KATALIS ZEOLIT $X$ DAN UJI AKTIFITAS DALAM PROSES PENUKARAN ION KALSIUM. Volume 33, Nomor 1

(103) Selly, Mers, Nirwana,2014. KAJIAN AWAL PENGARUH WAKTU REAKSI DAN RASIO MOLAR ASAM OLEAT DENGAN BUTANOL TERHADAP SIFAT FISIKO KIMIA PLASTISIZER BUTIL OLEAT. Vol 7, No 2 
${ }^{(104)}$ Ekowati, Juni.2010. Pengaruh Katalis pada Sintesis Asam O-Metoksisinamat dengan Material Awal O-Metoksi Benzaldehida dan Uji Aktivitas Analgesiknya. Vol 8, No 2

${ }^{(105)}$ Husin, Husni, Mahidin, Mahidin, Marwan, Marwan,2011. STUDI PENGGUNAAN KATALIS ABU SABUT KELAPA, ABU TANDAN SAWIT DAN K2CO3 UNTUK KONVERSI MINYAK JARAK MENJADI BIODIESEL. Vol 13, No 4

${ }^{(106)}$ Ismiyarto, Ismiyarto , Rejeki, Sri, Ngadiwiyana, Ngadiwiyana.2009. PENGARUH TEMPERATUR PADA SINTESIS ESTER ASAM LEMAK SELULOSA (FACE) MENGGUNAKAN KATALIS Na2CO3.Vol 17 No 1

(107) Agus Wibowo, Agus Wibowo, 2010. LAJU REAKSI PENCAMPURAN MINYAK JARAK DAN AIR PADA HYDROGEN REFORMER MENGGUNAKAN PEMANAS DAN KATALIS.Vol 1, No 1.

(108) Ngadiwiyana, Ngadiwiyana.2005. Polimerisasi Eugenol Dengan Katalis Asam Sulfat Pekat. Vol 8, No 2

${ }^{(109)}$ Fatimah, Is , Rubiyanto, Dwiarso, Huda, Torikul.2008. PERANAN KATALIS TiO2/SiO2-MONTMORILLONIT PADA REAKSI KONVERSI SITRONELAL MENJADI ISOPULEGOL.vol 12, no 2

(110) Windarti, Tri, Suseno, Ahmad.2004. Preparasi Katalis Zeolit Alam Asam sebagai Katalis dalam Proses Pirolisis Katalitik Polietilena. Vol 7, No 3

${ }^{(111)}$ Hartiniati.2006. HIDROKONVERSI KATALITIK RESIDU MINYAK BUMI: PENGARUH TEMPERATUR DAN WAKTU REAKSI. Vol 10, No 2

(112) Zainul, R. and Wardani, S. (2019) "The Hydrogen Generator Performance of Sandwich Designed 4/4 Al-Cu Plates", EKSAKTA: Berkala Ilmiah Bidang MIPA, 20(1), pp. 100-104. doi: 10.24036/eksakta/vol20-iss1/177.

(113) Hidayani, T. (2018) "GRAFTING POLIPROPILENA DENGAN MALEAT ANHIDRIDA SEBAGAI PENGIKAT SILANG DENGAN INISIATOR BENZOIL PEROKSIDA”, EKSAKTA: Berkala Ilmiah Bidang MIPA, 19(1), pp. 56-62. doi: 10.24036/eksakta/vol19-iss1/127.

(114) Dinata, M., Fitridawati, F. and Putri, L. (2019) "The Study Trees Potential for Forest in Universitas Lancang Kuning Pekanbaru", EKSAKTA: Berkala Ilmiah Bidang MIPA, 20(1), pp. 77-85. doi: 10.24036/eksakta/vol20iss $1 / 176$. 
(115) Susilaningrum, D. (2017) "PEMODELAN REGRESI LOGISTIK PADA FAKTOR YANG MEMPENGARUHI PHBS PADA RUMAH TANGGA PENDERITA TBC DI PESISIR SURABAYA", EKSAKTA: Berkala Ilmiah Bidang MIPA, 18(02), pp. 121-128. doi: 10.24036/eksakta/vol18-iss02/65.

(116) Sumarmin, R. (2018) "Pengaruh Ekstrak Kulit Buah Manggis (Garcinia mangostana L.) terhadap Histologis Pankreas Mencit (Mus musculus L. Swiss Webster) yang Diinduksi Sukrosa", EKSAKTA: Berkala Ilmiah Bidang MIPA, 19(1), pp. 100-112. doi: 10.24036/eksakta/vol19-iss1/123.

(117) Rizki Saputra, M. and Sumarmin, R. (2018) "PENGARUH EKSTRAK DAUN SIRIH MERAH (Piper crocatum Ruiz \& Pav.) TERHADAP GLUKOSA DARAH MENCIT (Mus musculus L.) JANTAN YANG DIINDUKSI SUKROSA”, EKSAKTA: Berkala Ilmiah Bidang MIPA, 19(1), pp. 43-55. doi: 10.24036/eksakta/vol19-iss 1/124.

(118) Huda, N. (2017) "PENGARUH EKSTRAK SAMBILOTO (Andrographis paniculata Nees.) TERHADAP SIKLUS ESTRUS MENCIT (Mus musculus L. Swiss Webster)", EKSAKTA: Berkala Ilmiah Bidang MIPA, 18(02), pp. 69-76. doi: 10.24036/eksakta/vol18-iss02/55.

(119) Putri, D., Fifendy, M. and putri, M. (2018) "DIVERSITAS BAKTERI ENDOFIT PADA DAUN MUDA DAN TUA TUMBUHAN ANDALEH (Morus macroura miq.)", EKSAKTA: Berkala Ilmiah Bidang MIPA, 19(1), pp. 125-130. doi: 10.24036/eksakta/vol19-iss1/122.

(120) Setianto, S. (2017) “ANALISA KUANTITATIF CAMPURAN SENYAWA OKSIDA SEBAGAI DASAR IDENTIFIKASI KANDUNGAN BAHAN SUMBER DAYA ALAM Studi Kasus : Kandungan Mineral pada Pasir Besi di Pesisir Pantai Selatan, Jawa Barat”, EKSAKTA: Berkala Ilmiah Bidang MIPA, 18(02), pp. 173-177. doi: 10.24036/eksakta/vol18-iss02/74.

(121) Tutuarima, T. (2017) "SIFAT FISIK DAN KIMIA MARMALADE JERUK KALAMANSI (Citrus microcarpa) : KAJIAN KONSENTRASI PEKTIN DAN SUKROSA Physical and Chemical Properties of Marmalade Citrus of Calamondin (Citrus microcarpa) : Study of Pectin and Sucrose Concentrations", EKSAKTA: Berkala Ilmiah Bidang MIPA, 18(02), pp. 164172. doi: 10.24036/eksakta/vol18-iss02/73.

(122) Syafei, N. (2019) "Events of corrosion phenomena on carbon steel pipes in environment of sea water and ammonia solutions due to the presence of sweet gas”, EKSAKTA: Berkala Ilmiah Bidang MIPA, 20(1), pp. 86-99. doi: 10.24036/eksakta/vol20-iss1/178. 
(123) Ruswandi, R. (2018) "Determination of Fructose Content resulted by Inulin Hydrolysis with DNS as Oxidizer", EKSAKTA: Berkala Ilmiah Bidang MIPA, 19(1), pp. 14-23. doi: 10.24036/eksakta/vol19-iss1/102.

${ }^{(124)}$ Dinata, A. A., Rosyadi, A. M., Hamid, S., \& Zainul, R. (2018, October 15). A Review CHEMICAL VAPOR DEPOSITION : PROCESS AND APPLICATION. https://doi.org/10.31227/osf.io/yfeau

${ }^{(125)}$ Rahmadhanty, S., \& Zainul, R. (2018, December 24). DESIGN OF HUMAT ACID SOLID SOLUTION REACTOR THROUGH PHOTOTRANSFORMATION OF COPPER OXIDE (CuO) SEMICONDUCTOR PLATE. https://doi.org/10.31227/osf.io/yhd9x

${ }^{(126)}$ Febriani, S. S., Yolanda, T., Arianti, V. A., \& Zainul, R. (2018, October 12). A Review Solid Stated : Principles and Methode. https://doi.org/10.31227/osf.io/7us4x

${ }^{(127)}$ Putri, D. F., Ritonga, H. M., Murdiati, V., \& Zainul, R. (2018, October 15). A REVIEW WHAT IS HYDROTHERMAL ?. https://doi.org/10.31227/osf.io/dm56c

(128) Kristy, D. P., \& Zainul, R. (2019, February 3). Analisis Molekular dan Transpor Ion Natrium Silikat. https://doi.org/10.31227/osf.io/8ac4m

(129) Nurdin , Kusharto, Clara Meliyanti, Tanziha, Ikeu, Januwati, M.2009. KANDUNGAN KLOROFIL BERBAGAI JENIS DAUN TANAMAN DAN $\mathrm{Cu}$-TURUNAN KLOROFIL SERTA KARAKTERISTIK FISIKOKIMIANYA. Vol 4, No 1

(130) Basri, M, Rukmi, Rukmi.2011. Jenis dan Kandungan Tanin Pakan Satwa Anoa (Bubalus sp.) Vol 34, No 1

(131) Goenarwo, Edijanti,2011. PENGARUH PEMBERIAN EKSTRAK ANGKAK TERHADAP KADAR HDL DARAH (Studi Eksperimental pada Tikus Jantan Galur Wistar yang Mendapat Diet Tinggi Lemak). Vol 49, No 125

(132) Wardani, Ratih Sari, Mifbakhuddin, Yokorinanti, Kiky.2010. PENGARUH KONSENTRASI EKSTRAK DAUN TEMBELEKAN (Lantana canara) TERHADAP KEMATIAN LARVA Aedes egypti. Vol 6, No 2

(133) Suprijono, Agus,sumarno , Rachmayanti, Lisa.2012. PENGARUH PEMBERIAN EKSTRAK GEMBILI (Dioscorea esculenta) TERHADAP PERTUMBUHAN VOLUME ADENOCARCINOMA MAMMAE MENCIT 
BETINA C3H Studi Eksperimental pada Mencit Betina Strain C3H yang Telah Diinokulasi dengan Bubur Tumor. Vol 50, No 128

(134) Nur, Hasna Hayati,2012. ANALISIS KANDUNGAN NITRIT DALAM SOSIS PADA DISTRIBUTOR SOSIS DI KOTA YOGYAKARTA TAHUN 2011. Vol 6, No 1

(135) Rahman, Erwid Fatchur,2010. Efektivitas Ekstrak Daun Dewa (Gynura Pseudochina (Lour.) Dc) Terhadap Pertumbuhan Candida Albicans Pada Plat Dasar Gigi Tiruan Resin Akrilik. Vol 48, No 123

(136) Maricar, Shyama, ,2011. STUDI PEMANFAATAN PARTIKEL KOMPOS UNTUK PEMBUATAN BATAKO RINGAN. Vol 13, No 1

(137) Slamet, Sugeng,2013. KARAKTERISASI KOMPOSIT DARI SERBUK GERGAJI KAYU ( SAWDUST ) DENGAN PROSES HOTPRESS SEBAGAI BAHAN BAKU PAPAN PARTIKEL.Vol 1, No 1

(138) S, Darmawati, S.S., Dewi,2008. EFEK EKSTRAK BUAH PARE (Momardica charantia, L) TERHADAP ZONE HAMBATAN PERTUMBUHAN Salmonella typhi PENYEBAB SALMONELLOSIS. Vol 1 , No 1

(139) Utama, Cahya Setya, Sumarsih, Sri,2010. Pengaruh Penambahan Aras Ekstrak Kubis Sortir dan Lama Pemeraman Terhadap Kandungan Nutrisi Silase Ikan. Vol 3, No 1

(140) DATTU IFFAH H,DWI JAYANTI GUNANDINI, AGUS KARDINAN,2008. Pengaruh Ekstrak Kemangi (Ocimum basilicum forma citratum) terhadap Perkembangan Lalat Rumah (Musca domestica) (L.) Vol 5 , No 1

(141) Safithri, Mega, Fahma, Farah, Marlina, Paramitha Wirdani Ningsih,2012. ANALISIS PROKSIMAT DAN TOKSISITAS AKUT EKSTRAK DAUN SIRIH MERAH YANG BERPOTENSI SEBAGAI ANTIDIABETES. Vol 7, No 1

(142) Setyaningsih, Dwi, Rusli, Meika Syahbana, Muliati, Nurmalia,2007. Sifat Fisiokimia dan Aroma Ekstrak Vanili. Vol 12, No 3

(143) Nurcahyanti, Agustina D. R., Dewi, Lusiawati -, Timotius, Kris H.2011. AKTIVITAS ANTIOKSIDAN DAN ANTIBAKTERI EKSTRAK POLAR DAN NON POLAR BIJI SELASIH (Ocimum sanctum Linn) [Antioxidant and Antibacterial Activities from Polar and Non Polar Basil (Ocimum sanctum Linn) Seed Extracts]. Vol 22, No 1 
(144) Septiana, Aisyah Tri, Muchtadi, Deddy, Zakaria, Fransiska R.2002. AKTIVITAS ANTIOKSIDAN EKSTRAK DIKHLOROMETANA DAN AIR JAHE (Zingiber officinale Roscoe) PADA ASAM LINOLEAT [Antioxidant Activity of Ginger (Zingiber officinale Roscoe) Dichloromethane and Water Exctract on Linoleic Acid]. Vol 13, No 2

${ }^{(145)}$ Fifteen Aprila Fajrin,2009. AKTIVITAS ANTIDIARE EKSTRAK ETANOL DAUN SELEDRI (Apium graveolens L) PADA MENCIT JANTAN. Vol 6, No 1

(146) Hartoyo, Arif , Muchtadi, Deddy, Astawan, Made , Dahrulsyah , Winarto, Adi,2011. PENGARUH EKSTRAK PROTEIN KACANG KOMAK (Lablab purpureus (L.) Sweet) PADA KADAR GLUKOSA DAN PROFIL LIPIDA SERUM TIKUS DIABETES [Effect of Protein Extract of Hyacinth Bean (Lablab purpureus (L.) sweet) on Glucose and Lipid Profiles Serum In Diabetic Rats]. Vol 22, No 1

(147) Hady Anshory, Suparmi Suparmi, Arif Setiadi Tamimy,2006. AKTIVITAS ANTIOKSIDAN EKSTRAK ETANOL KULIT BUAH RAMBUTAN (Nephelium lappaceum L. ) TERHADAP PENANGKAPAN RADIKAL BEBAS DPPH. Vol 3, No 1

${ }^{(148)}$ Dewi, Utari Kusuma, Saraswati, Tyas Rini,2009. Efek Rebusan Daun Tapak Dara pada Dosis dan Frekuensi yang Berbeda terhadap Kerusakan dan Akumulasi Glikogen pada Hepar Mencit (Mus musculus). Vol. 11, No. 1

(149) Chodidjah, Widayati, Eni , Utari, Utari,2007. Pengaruh pemberian air rebusan meniran (Phyllanthm niruriLinn) terhadap gambaran histopatologi hepar tikus wistar yang terinduksi CCL4. Vol 1, No 2

(150) Rofik, Dwi Ratnani, Rita,2012. EKSTRAK DAUN API-API (Avecennia Marina) UNTUK PEMBUATAN BIOFORMALIN SEBAGAI ANTIBAKTERI IKAN SEGAR. Vol 1, No 1 